The Impact of Mass Migration on the Israeli Labor Market

Rachel M. Friedberg

Brown University and NBER

August 1997

Funding from the Falk Institute is gratefully acknowledged. Data were provided by the Social Sciences Data Archive at the Hebrew University of Jerusalem. Vadim Marmer provided outstanding research assistance. I thank Joshua Angrist, Moshe Buchinsky, Jennifer Hunt, Lawrence Katz, and seminar participants at Hebrew University, Tel Aviv University, the Bank of Israel, Brown, Yale, Boston College, MIT, Harvard, Princeton, PAA, and the NBER for helpful comments. 


\title{
The Impact of Mass Migration on the Israeli Labor Market
}

\begin{abstract}
Mass migration from the former Soviet Union increased the Israeli population by $12 \%$ in the first half of the 1990s. This exodus was precipitated by the lifting of emigration restrictions in an unstable USSR and by the open immigration policy of Israel toward Soviet Jews, who faced more restrictive entry policies elsewhere. I use this natural experiment to study the impact of immigration on the labor market outcomes of native Israelis. OLS yields significant reductions in wages and small reductions in employment. However, OLS is biased if the distribution of immigrants across occupations in Israel was not exogenous to relative wage and employment conditions. I instrument for the entry of Russians into an occupation in Israel, using information on their former occupations in the USSR. There is a significant positive correlation between the former presence of the immigrants in an occupation in the USSR and their presence in that occupation in Israel. But the previous occupational choices of Russians abroad were independent of Israeli wage and employment growth subsequent to their migration. IV estimates indicate that immigration did not have an adverse impact on native Israeli labor market outcomes.
\end{abstract}

Rachel M. Friedberg

Department of Economics

Brown University

Providence, RI 02912

and NBER

rachel_friedberg@brown.edu 
JEL Classification: J6, J31, J2 


\section{Introduction}

Since the beginning of the decade, Israel has experienced an immigration of massive proportions from the former Soviet Union. Approximately 700,000 immigrants from the FSU have come to the country since 1989, increasing the population by over seven percent in the space of just two years, and by twelve percent in the first half of the 1990s. The aim of this paper is to use this natural experiment to analyze the impact of immigration on the receiving labor market. In particular, the goal is to determine whether there have been adverse effects on the labor market outcomes of the "native" Israeli population. ${ }^{1}$

There has been much research recently into the question of how immigration affects the labor market outcomes of natives. In the simplest supply and demand model of the labor market, immigration causes an outward shift in the labor supply curve. ${ }^{2}$ Assuming imperfectly elastic labor supply and demand curves, equilibrium wages will fall, and equilibrium employment will rise, but by less than the size of the immigration. Immigrants will therefore displace some natives in employment. However, despite the popular belief that immigrants have a large adverse impact on the wages and employment opportunities of the native-born population, the research in this area is not largely supportive of that

\footnotetext{
${ }^{1}$ The terms "Israelis" and "natives" will be used to refer to veteran Israelis, whether born in Israel or abroad. The terms "Russians" and "immigrants" will be used to refer to the recent immigrants from Russia and other parts of the Soviet Union and former Soviet Union.

${ }^{2}$ Immigration may also cause an outward shift in the labor demand curve, but this is typically assumed to be of a smaller magnitude, particularly in the short run or by sector. In a model of wage differentials, if immigrants and natives have different skill distributions, but similar consumption bundles, immigration shifts the relative supply curves of certain groups of workers, with little or no change in the relative demand curves. This textbook model assumes that workers are perfect substitutes. Native workers who are, in fact, gross complements with immigrant labor should experience a rise in both wages and employment as a result of immigration.
} 
conclusion. $^{3}$ Estimated employment effects are quite weak, and there is not a consensus as to the size of immigration's impact on wages. Most studies have found that a $10 \%$ increase in the fraction of immigrants in the population reduces native wages by $1 \%$ at most. ${ }^{4}$

Previous empirical work has followed three major approaches. Studies exploiting geographic variation correlate variation in immigration and changes in native outcomes across cities (Altonji and Card, 1991; Goldin, 1994; LaLonde and Topel, 1991; Pischke and Velling, 1994). Factor proportions analyses calculate the changes in the supply of different skill groups implied by immigration and combine them with estimates of labor demand elasticities to gauge the change in native wages (Borjas, Freeman, and Katz, 1992, 1996, and 1997; Jaeger, 1996). This approach yields more sizeable effects of immigration than the geographic approach. Finally, studies of natural experiments analyze migrations induced by political factors in the sending country (Card, 1990; Hunt, 1992; Carrington and DeLima, 1996). These studies have not found a significant effect of immigration on native outcomes. $^{5}$

In this paper, I provide new evidence on immigration's impact on the host labor market, using an approach that combines use of a natural experiment with a novel

\footnotetext{
${ }^{3}$ See Friedberg and Hunt (1995) for a review of the literature.

${ }^{4}$ Aspects of some of the empirical approaches would suggest that these estimated elasticities probably overstate the true effect, although recent work by Borjas, Freeman, and Katz (1996) argues that the impact is in fact understated in much of the literature, due to factor price equalization.

${ }^{5}$ Empirical research on the Russian mass migration to Israel has focussed on the labor market adjustment of the new immigrants themselves, rather than their impact on native outcomes (Beenstock and Ben Menahem, 1995; Eckstein and Shachar, 1995; Flug and Kasir, 1993; Flug, Kasir and Ofer, 1992; and Weiss and Gotlibovski, 1995). Theoretical research has explored the potential effects of this wave on macroeconomic variables such as growth, aggregate unemployment, and the aggregate returns to labor and capital (Beenstock and Fisher, 1996; Brezis and Krugman, 1996; Flug, Hercowitz, and Levi, 1994; Hercowitz and Meridor, 1991 and 1993; Hercowitz, Kantor and Meridor,
} 
instrumental variable which exploits detailed data on immigrants' occupations in their country of origin. ${ }^{6}$ My results support the view that immigrants do not adversely affect the earnings or employment opportunities of native workers.

There are four reasons the Russian migration to Israel makes a particularly interesting case study of immigration's impact on the receiving labor market. First, this wave of immigration was large and concentrated. In 1990 alone, Russian immigration lead to population growth of four percent in Israel, with an average annual rate of $1.4 \%$ sustained over the seven-year period 1989-95. No immigration to the United States or Western Europe has been comparable in magnitude. At the peak of mass migration to the United States at the beginning of the century, the rate of population growth due to immigration was one percent per year, and U.S. immigration is still considered an important issue by economists and policymakers at its current rate of only about $0.35 \%$ per year.

Second, this case provides an exogenous source of variation for studying the effects of immigration on the labor market. The migration was precipitated by the lifting of emigration restrictions in the Soviet Union. Due to the unstable political and economic climate in the former USSR, the majority of the Jewish community chose to emigrate. They chose to leave because of conditions in the FSU, and, in most cases, they went to Israel simply because it was their only option. ${ }^{7}$ The migration was therefore exogenous to economic conditions in Israel and the immigrants freer of the self-selection which generally

1993; Weiss and Ben David, 1994).

${ }^{6}$ Equivalent data are not available for the United States.

7 At around the same time, the United States changed its immigration laws, making it more difficult for Russians to enter the United States. 
arises as an important issue in studies of immigration.

Third, Israel is a very small country. For most purposes, it may be considered to be a single labor market. The inability of many studies to detect an impact of immigration on labor market outcomes in the United States and Europe may be due to a diffusion of immigration's local effects through factor price equalization with a large unaffected geographic area. In Israel, this problem is not present.

The final reason this case is of particular interest is the unusual skill composition of the new immigrants from Russia. Virtually all of the existing literature in this area has studied inflows of workers less-skilled than the average native. The Russian immigrants to Israel are highly educated and have come with a good deal of labor market experience. While the short-run impact may be the same, the reaction of the labor market in the long run to an inflow of highly-educated immigrants may be different from its reaction to one with less human capital. ${ }^{8}$

The next section of the paper provides some background on the evolution of immigration and labor market conditions in Israel. Section III provides a theoretical framework for analyzing the impact of immigration on the earnings of native workers. The econometric framework for the empirical analysis is laid out in Section IV, and the data and variables used are described in Section V. Section VI reports the empirical findings, and the final section concludes.

\footnotetext{
${ }^{8}$ For example, since many immigrants lack the language skills needed to work in their professions upon arrival, it may be that they initially compete with less-skilled natives for blue-collar jobs. As they assimilate, they may move out of that sector and begin to compete at the high-skill end of the labor market. For this reason, the impact in certain (low skill) sectors may dissipate, and in other (high skill) sectors may occur only with a lag, but display more persistence. That persistence will be mitigated, to the extent that the concentration of highly educated labor (e.g., medical doctors, engineers, etc.) attracts capital in the long run. Research on this pattern must await the long run.
} 


\section{Background}

Beginning with the pre-State waves of migration and culminating in the mass migrations from Europe and the Arab World following Independence in 1948, Israel has been a country characterized by a high level of immigration. Currently, approximately half of the population is foreign-born. Immigration to Israel in the period $1980-95$ is presented in Figure One. ${ }^{9} \quad$ Through most of the 1980s, approximately one thousand immigrants arrived per month. At the end of 1989, immigration rose sharply, with the beginning of the mass migration from Russia. At the peak of the wave, 36,000 Russians immigrated to Israel in a single month. Between 1989 and 1995, 610,100 immigrants arrived from the FSU, increasing the size of the Israeli population by $13.6 \%$.

Casual empirical observation suggests that the changes in wages which occurred in Israel over this period are consistent with a large increase in labor supply. Figure Two displays the time-series of real wages for 1980-94. With the exception of the recession of 1982 and the hyperinflation and stabilization of $1984-85$, real wages grew rapidly through the 1980s. Beginning in 1989, however, the real wage began a three-year decline, followed by stagnation for the rest of the period.

The quarterly aggregate unemployment rate is displayed in Figure Three. The high rates at the beginning of the 1990s are consistent with the arrival of large numbers of immigrants. However, the timing indicates that the increase was at least partly due to other causes. The rise in unemployment began in mid-1988, preceding the immigration by more than a year. It is also notable that by 1995, the unemployment rate had already fallen to a

\footnotetext{
${ }^{9}$ The uptick at the end of 1984 marks "Operation Exodus," an airlift of refugees from Ethiopia. The trough in early 1991 marks the Gulf War.
} 
level lower than at the beginning of the mass migration.

While these wage and unemployment patterns are suggestive, caution must be taken in their interpretation. First, the aggregate real wage and unemployment rate series in Figures Two and Three are composites of the respective averages for the new immigrants and the native population. Since new immigrants earn less and have higher unemployment rates than natives, the changes in these labor market variables could partly reflect a change in the composition of the labor force, rather than any impact of immigration on the labor market outcomes of natives. Estimates of the wage and unemployment rate gaps between natives and the new immigrants, however, point to this composition effect being quite small. $^{10}$ In the empirical analysis below, the problem of distinguishing composition from impact effects will be eliminated through the use of microdata on native Israelis alone.

A second caveat to drawing conclusions from simple time-series is that the Russian immigration was by no means the only major macroeconomic event in Israel during this time period. Other major events included the Palestinian uprising (or "Intifada"), which began in 1987, the Persian Gulf War in 1991, and the signing of the Oslo peace accords in 1993. For this reason, any analysis will obviously require sources of variation other than time. The analysis below will focus on changes in relative wages and employment across occupations, exploiting the fact that the occupational composition of the Russian immigrants is different from that of the native Israeli population.

\section{Theory}

${ }^{10}$ See Beenstock and Ben Menahem (1995), Eckstein and Shachar (1995), Flug and Kasir (1993), Flug, Kasir and Ofer (1992), and Weiss and Gotlibovski (1995). 
Before examining the data, it is useful to consider what impact conventional models predict immigration will have on the labor market outcomes of natives. Theory also provides insight into the conditions under which the empirical researcher will or will not be able to detect that impact.

Taking the most restrictive case first, consider a closed economy model, with no international flows of goods or capital, in which production takes place using capital and labor. If there is only one type of labor, then an influx of immigrants will reduce the capitallabor ratio and thus lower the wage. In a model with more than one type of labor, the effect of immigration on natives' labor market outcomes will depend on the degree of substitutability between immigrant and native workers. Immigrants will raise the wages of workers with whom they are complements in production or gross complements (i.e., substitutes in production for whom the scale effect exceeds the substitution effect). Immigrants will lower the wages of workers with whom they are gross substitutes. This negative effect will be magnified if immigrants are prepared to work for less than natives.

If labor supply is perfectly inelastic, immigration will not affect native employment. If, however, labor supply and labor demand are both imperfectly elastic, native employment will move in the same direction as wages, and the change in wages will be smaller than in the former case.

In an open economy model, compensating international flows of factors of production or of goods embodying them (as in Heckscher-Ohlin) will offset any changes in wages or returns to capital caused by immigration, so that such effects will only exist in disequilibrium. In equilibrium, factor prices will be equalized across countries. In this case, immigration will not yield cross-country differences in wages, and it would be fruitless to 
look across countries to learn the effect of immigration on the labor market. ${ }^{11}$ The degree of factor price equalization (FPE) will depend upon the freedom with which goods and factors can flow to arbitrage price differentials.

Many studies exploit geographic variation in immigration within a country to search for evidence of immigration's impact. Analogously to the cross-country setting, whether an uneven distribution of immigrants across cities will result in cross-sectional differences in labor market conditions depends on the degree to which FPE holds within the country. There are fewer barriers to trade and factor flows across regions than across countries, so that FPE is more likely to hold within countries than between them. In the presence of full domestic FPE and the absence of international FPE, immigration will affect the aggregate wage of a country, but not the relative wages of cities in that country. Immigration's impact will not be observable along the geographic dimension because any incipient local effects will be diffused by the migration of native workers out of the high-immigration cities, by capital inflows into them, or by inter-city trade.

In this paper, I use a new approach to detecting the impact of immigration on native labor market outcomes. Because movement across occupations is not as free as movement across locations, FPE poses less of a problem in an analysis using cross-occupation variation than in one using cross-city variation. People are free to move from one city to another in search of better earnings opportunities. Occupational mobility is more restricted and often requires a large investment in retraining, greatly reducing the speed and extent to which workers respond to changes in the occupational wage structure. Equilibrium may only be

\footnotetext{
${ }^{11}$ Immigration will lead to growth in the tradables sector, with the country's relatively high labor endowment reflected in the export of relatively labor-intensive goods.
} 
restored by the changing occupational choices of new labor market entrants. Disequilibrium across occupations will therefore be more persistent than disequilibrium across local labor markets, and the impact of immigration more readily apparent.

\section{A. A Simple Model of the Labor Market}

Consider a model of the labor market in a closed economy. There are two periods, 0 and 1 , indexed by $\mathrm{t}$. There are $\mathrm{J}$ occupations, indexed by $\mathrm{j}$. Employment of native workers in occupation $\mathrm{j}$ at time $\mathrm{t}$ is denoted by $\mathrm{N}_{\mathrm{jt}}$. Assume that between periods 0 and 1 , immigration occurs. Employment of immigrant workers is denoted by Rit, with Rjo equal to zero by definition. Total employment in an occupation, Ejt, is equal to $\mathrm{Njt}_{\mathrm{jt}}+\mathrm{Rjt}$. Finally, define $\mathrm{rjt}_{\mathrm{jt}}$ as $\mathrm{R}_{\mathrm{j} t} / \mathrm{N}_{\mathrm{jt}}$, the ratio of immigrant to native workers.

The labor market has a constant elasticity labor demand function of the form:

$$
\ln \left(E_{j t}{ }^{D}\right)=\ln \left(S_{j}\right)+\eta \ln \left(W_{j t}\right)
$$

where $S_{j}$ is a demand shifter, capturing the fact that some occupations have higher levels of employment than others, for reasons unrelated to wages. For example, there is less demand in the economy for piano tuners than for teachers. Assume that the labor market is in equilibrium in period 0 , so that wages are equalized across all occupations, with $W_{j 0}=W_{0}$ for all $\mathrm{j}$. Since in period $\mathrm{O}, \mathrm{E}_{\mathrm{j} O}=\mathrm{Njo}$, labor market equilibrium is given by:

$$
\ln \left(\mathrm{N} j o_{0}\right)=\ln \left(\mathrm{S}_{\mathrm{j}}\right)+\eta \ln \left(\mathrm{W}_{0}\right)
$$

In period 1, labor market equilibrium is given by:

$$
\ln \left(N_{j 1}+R_{j 1}\right)=\ln \left(S_{j}\right)+\eta \ln \left(W_{j 1}\right)
$$

Assume that, because of the existence of occupation-specific human capital or because labor market re-equilibration happens only slowly, in the short run, workers do not switch 
occupations in response to changes in relative wages, so that $\mathrm{Njo}_{\mathrm{j}}=\mathrm{Nj}_{1}=\mathrm{Nj}^{12}$ Substituting equation (2) into equation (3) and rearranging terms yields:

$$
\begin{gathered}
\ln \left(\mathrm{W}_{\mathrm{j} 1}\right)=(1 / \eta) \ln \left(\left(\mathrm{N}_{\mathrm{j}}+\mathrm{R}_{\mathrm{j} 1}\right) / \mathrm{N}_{\mathrm{j}}\right)+\ln \left(\mathrm{W}_{0}\right) \\
\ln \left(\mathrm{W}_{\mathrm{j} 1}\right) \cong(1 / \eta)\left(\mathrm{R}_{\mathrm{j} 1} / \mathrm{N}_{\mathrm{j}}\right)+\ln \left(\mathrm{W}_{0}\right) \\
\ln \left(\mathrm{W}_{\mathrm{j} 1}\right) \cong \text { constant }+(1 / \eta) \mathrm{r}_{\mathrm{j} 1}
\end{gathered}
$$

Since the elasticity of labor demand $\eta<0$, the wage in a given occupation will be negatively related to the presence of immigrants in that occupation.

\section{B. A Labor Market Model with Inter-Occupation Wage Differentials}

The above model assumes that wages are equalized in the initial equilibrium. An alternative assumption is that there exist equilibrium occupational wage differences, due, for example, to compensating differentials. In this case, $W_{j o}=W_{0} D_{j}$, with $D_{j}$ defining the occupation fixed-effect on wages. In period 0 , labor market equilibrium is given by:

$$
\ln \left(\mathrm{N}_{\mathrm{j}}\right)=\ln \left(\mathrm{S}_{\mathrm{j}}\right)+\eta \ln \left(\mathrm{W}_{\mathrm{o}}\right)+\eta \ln \left(\mathrm{D}_{\mathrm{j}}\right)
$$

Labor market equilibrium in period 1 is as given in equation (3). Substituting equation (7) into equation (3) and replacing $\ln \left(\mathrm{W}_{0}\right)$ with $\ln \left(\mathrm{W}_{\mathrm{j}}\right)-\ln \left(\mathrm{D}_{\mathrm{j}}\right)$ :

$$
\begin{gathered}
\ln \left(N_{j}+R_{j 1}\right)=\ln \left(N_{j}\right)-\eta\left(\ln \left(W_{j 0}\right)-\ln \left(D_{j}\right)\right)-\eta \ln \left(D_{j}\right)+\eta \ln \left(W_{j 1}\right) \\
\ln \left(W_{j 1}\right)-\ln \left(W_{j 0}\right)=1 / \eta \ln \left(\left(N_{j}+R_{j 1}\right) / N_{j}\right) \\
\ln \left(W_{j 1}\right)-\ln \left(W_{j 0}\right) \cong(1 / \eta) r_{j 1}
\end{gathered}
$$

Wage growth within an occupation will be negatively related to the proportionate inflow of immigrants to that occupation. Therefore, variation in the influx of immigrants across

\footnotetext{
12 This assumption is relaxed in the empirical work.
} 
occupations can be used to measure the effect of immigration on native earnings. Depending on the importance of fixed inter-occupation wage differentials, one can compare the level or change in earnings with the level or change in immigration.

A key assumption of the preceding models is that the distribution of native and immigrant workers across occupations is exogenous to wages. The implications of relaxing that assumption are laid out in the section on empirical methodology.

\section{Estimation Framework}

\section{A. Individual-Level Analysis}

The most direct approach to estimating the effect of immigration on the earnings of native workers is to estimate an individual-level earnings function, including a measure of immigration as one of the independent variables:

Install Equation Editor and double-

click here to view equation.

where $\mathrm{Wit}_{\mathrm{ijt}}$ is the log earnings of individual $\mathrm{i}$ in occupation $\mathrm{j}$ at time $\mathrm{t}, \mathrm{X}_{\mathrm{it}}$ is a vector of control variables, such as schooling, labor market experience, etc., $\alpha_{t}$ is a year dummy, occik are a set of $\mathrm{J}$ occupation dummy variables, and $\mathrm{rit}$ is the ratio of immigrant to native workers in the individual's occupation.

By pooling data from multiple time periods, this specification implicitly estimates the change in wages associated with a change in the presence of immigrants in an individual's occupation. The vector of coefficients on the occupation dummy variables $(\delta k)$ capture interoccupation wage differentials which do not vary with time. The year dummy $(\alpha t)$ captures average wage growth which does not vary with occupation. Therefore $\gamma$, the coefficient on 
$r$, reflects the difference in wage growth experienced by natives in occupations with larger or smaller inflows of immigrants. Put in other words, $\alpha$ and $\delta$ capture the "main effects" of year and occupation, while $\gamma$ captures their interaction in a particular form. In the present case, $\gamma$ will reflect the degree to which native wage growth in an Israeli occupation between 1989 and 1994 varied with the extent of Russian immigration into that occupation over the same time period. This individual-level regression is thus comparable to a changes regression at the group level, rather than to a levels regression.

\section{B. Occupation-Level Analysis}

\section{The Cross-Sectional Approach}

In many existing studies of immigration, the unit of observation is not the individual native worker, but rather a more aggregated unit, such as the city or region. For this reason, as well as to enable an analysis of employment and to highlight certain features of the data, it is useful to conduct the analysis at the group level as well as at the individual level. The unit of observation will be the 2-digit occupation. To study the impact of immigration on native wages and employment at the group level, the most basic approach is to regress the labor market outcome of interest on the presence of immigrants, i.e., the ratio

or share of immigrants in the relevant population. In the case of wages, the regression specification is:

$$
W_{j}=\alpha+X_{j} \beta+\gamma r_{j}+\varepsilon_{j}
$$

where $W_{j}$ is the average native log wage in occupation $j, X_{j}$ is a vector of occupation-specific factors which could affect the level of wages (for example, the average age and education of the workers in the occupation, the industry mix of employment, etc.), and $\mathrm{r}_{\mathrm{j}}$ is the relative 
number of workers in the occupation who are immigrants.

A potential problem with this approach is endogeneity. Immigrants may in fact depress wages, meaning that $\gamma<0$. However, if the distribution of immigrants across occupations is not independent of $\varepsilon$, the unobserved determinants of wages, then the conditional correlation of wages and immigrant density will confound the two directions of causality, and the estimate of $\gamma$ will be biased. If immigrants choose occupations offering higher wages (i.e., occupations with high $\varepsilon^{\prime}$ ), the estimate of $\gamma$ will be biased upward, leading to an underestimate of immigration's negative impact on wages. If, on the other hand, immigrants are confined to low paying occupations, the estimate of $\gamma$ will be biased downward, leading to an overestimate of immigration's effect.

This endogeneity problem would seem to be quite serious when considering geographic variation in immigration, since local wages are likely to be an important factor influencing immigrants' locational choices. Endogeneity is probably less of a problem along the occupational dimension, as immigrants cannot freely choose to enter any occupation, but are limited by their qualifications, skills, etc. At least in the short run, before they can undertake new training, immigrants' occupational choice may be relatively independent of occupational wages.

\section{The Multiple Cross-Section Approach}

If immigrants do choose occupations on the basis of their wage levels, but not their wage growth, an endogeneity problem present in the first approach can be circumvented by using more than one cross-section of data. In this approach, the change in wages over time 
is regressed on the inflow of immigrants over time: ${ }^{13}$

$$
\left(W_{j, t}-W_{j, t-k}\right)=(\alpha t-\alpha t-k)+\left(X_{j, t}-X_{j, t-k}\right) \beta+\gamma\left(r_{j, t}-r_{j}, t-k\right)+(\varepsilon j, t-\varepsilon j, t-k)
$$

The estimated value of $\gamma$ will measure the impact of immigrant inflows on wage growth, and will not reflect any simultaneous causality in the other direction. This approach has the benefit of differencing out any observable or unobservable fixed effects in wage levels. If, however, immigrant flows are not independent of occupational wage growth, the problem of endogeneity will still be present in the differenced estimation.

\section{The Instrumental Variables Approach}

When both the single and multiple cross-section approaches suffer from endogeneity bias, it becomes necessary to use an instrumental variables approach. In order to identify the parameter of interest, $\gamma$, a source of independent variation in immigration must be found. In the multiple cross-section setting, the instrument must be correlated with the inflow of immigrants into an occupation but uncorrelated with the unobserved component of wage growth in that occupation subsequent to their arrival, except through its correlation with immigration.

A source of exogenous variation in the entry of Russian immigrants into occupations in Israel may be found in the immigrants' previous occupational distribution abroad. Because workers have occupation-specific human capital, their earnings will tend to be highest ${ }^{14}$ in the occupation in which they have the most training and experience. For this reason, as

\footnotetext{
${ }^{13}$ Note that in the case in which the immigration occurs between time $t-k$ and time $t, r j, t-k$ equals zero, so that the variable measuring immigration is the same as in the single cross-section specification.

${ }^{14}$ relative to the occupational mean
} 
well as because their previous occupational choices revealed something about their preferences, immigrants will tend to seek work in their former occupations. Thus, if the immigrant wave contained a large number of former engineers, we would expect the labor supply shock to engineering in Israel to be large, relative to the shock to other occupations. This source of variation is independent of the wages of engineers in Israel, relative to wages in other occupations. An immigrant's previous occupation in Russia was chosen on the basis of labor market conditions in Russia and his individual preferences. It preceded the immigrant's encounter with labor market conditions in Israel. ${ }^{15}$

The labor market assimilation of immigrants takes time, and it is known that immigrants often experience occupational downgrading upon their initial arrival in the host country. Some immigrants remain in these lower occupations permanently. With time, and subject to imperfect human capital transferability, others move back into their former professions. Yet others enter a new occupation. The relative prevalence of these three patterns is not crucial here. For the purpose of identifying an instrument, the previous occupational distribution of the immigrants need only be correlated with their occupational distribution in Israel and uncorrelated with the Israeli wage structure subsequent to their arrival.

Let $\mathrm{P}_{\mathrm{jt}}$ be the number of Russian immigrants in Israel at time $\mathrm{t}$ who worked in occupation $\mathrm{j}$ in Russia. Pjt will serve as the instrumental variable for $\mathrm{R}_{\mathrm{jt}}$, the number of Russian immigrants in Israel at time $\mathrm{t}$ who work in occupation $\mathrm{j}$ in Israel. Since in the

15 The fact that the mass migration was a surprise to both the Russians immigrants and to the Israelis strengthens the independence of the Russians' occupational choices and Israeli labor market conditions. This point will be discussed in more detail in the section on the data used to construct the instrument. 
specifications above, the independent variable, $\mathrm{rjt}_{\mathrm{jt}}=\mathrm{R}_{\mathrm{jt}} / \mathrm{N}_{\mathrm{jt}}$, is in the form of a ratio, $\mathrm{Pjt}$ must also be scaled by the size of the occupation. In order to allow for the possible endogeneity of $\mathrm{N}_{\mathrm{jt}}$ as well as $\mathrm{R}_{\mathrm{jt}}$, the variable used to instrument for $\mathrm{rjt}_{\mathrm{jt}}$ will be $\mathrm{pjt}_{\mathrm{jt}}$, defined as $\mathrm{P}_{\mathrm{jt}} / \mathrm{N} j \mathrm{j}$, where $\mathrm{Njo}$ is native employment before the immigration. Both $\mathrm{p}_{\mathrm{j} 0}$ and $\mathrm{rjo}$ are equal to zero by definition.

\section{Data and Variables}

\section{A. The Instrument}

In contrast to the United States, which has no such data, in Israel, there exist several panel surveys of new immigrants. The most recent Immigrant Employment Survey (IES) surveys a large sample of new immigrants who arrived in Israel in 1990. The dataset includes information on conditions before migration (previous occupation, education, training, language skills, etc.) as well as current labor market information at several points in time. The information on the immigrants' former occupation in Russia is the variable which will serve as an identifying instrument in the analysis below.

The fact that these immigrants were among the earliest arrival cohorts of the mass migration strengthens the argument that the instrumental variable constructed on the basis of this group is independent of labor market conditions in Israel. To the extent that information about those conditions filtered back to the FSU, informing potential subsequent immigrants about relative earnings in Israel and causing selection in migration, this group of immigrants arrived early enough that this need not be a concern. Information about the Israeli labor market simply was not available in Russia at the time these immigrants left. In addition, the emigrants who left first were the ones most eager to flee, the group for whom 
concern about the unstable situation in Russia was sufficiently strong that the decision to emigrate was immediate. Even if detailed information about job opportunities in Israel had been readily available, it is very unlikely that it would have lead to selective emigration among this group.

Figure Four shows the distribution of new Russian immigrants to Israel across occupations in Israel in 1994 and across occupations in Russia preceding migration. ${ }^{16}$ Each observations is denoted by its 2-digit occupation code. A list of these codes is provided in an appendix. The relatively flat line on the graph is given by the fitted values from an OLS regression of the number of Russians by occupation in Israel on the number of Russians by occupation abroad. This regression yields a coefficient of .283 (standard error $=.075$ ) with an $\mathrm{R}^{2}$ of $0.14 .^{17}$

If no Russians switched occupations following migration, all points would lie along the 45-degree line. The points most vertically distant from the line represent occupations to and from which the Russians disproportionately switched. The most important former occupations of Russians were engineer, manager, physician, and teacher. In contrast, the most important occupations of Russians in Israel are service worker, welder, and housemaid. These occupations also had the most outflows and inflows, respectively.

\footnotetext{
${ }^{16}$ Specifically, it graphs the number of Russians employed in the occupation in Israel in the 1994 LFS against the number of Russians formerly employed in the occupation in the USSR in the IES, scaled to have the same total. Figure Five presents the same graph, telescoped in on the smaller occupations.

${ }^{17}$ The correlation coefficient between $\mathrm{R}$ and $\mathrm{P}$ is therefore 0.37 . Among the occupations with low $R$ and $P$, shown in Table Five, the correlation coefficient is 0.6 . However, the OLS regression line shown in Figure Five is the same as in Figure Four, i.e., based on the full sample.
} 


\section{B. Microdata on Israelis}

The primary data source used in the analysis below is the microdata of the Israel Income Surveys (IS) and Labor Force Surveys (LFS) of 1989 and 1994, the last year preceding the mass migration from Russia and the most current year available, respectively. The IS is conducted on the fourth rotation group of the LFS, which is a household survey similar to the U.S. Current Population Survey. ${ }^{18}$

Table One presents descriptive statistics for native Israelis and new Russian immigrants in the 1994 IS and LFS microdata. The sample used includes all employees aged 25-65 who are not self-employed. ${ }^{19}$ The reason for excluding those under the age of 25 is that in these data, for military security reasons, all individuals aged 18-24 are coded as being aged 22. Unfortunately, this makes it difficult to study new labor market entrants, a group that could be particularly vulnerable to labor market competition from new immigrants.

New Russian immigrants comprise $13 \%$ of this sample. On average, the Russians are one year older and have one more year of schooling than the Israelis. ${ }^{20}$ The average new Russian immigrant had been in Israel 3.1 years at the time of the survey. Among "native" Israelis, 39.2\% are foreign-born, having arrived in Israel 31.5 years earlier on average.

\footnotetext{
${ }^{18}$ The sampling frame of the IS includes only urban residents, and the variable definitions are often coarser than in the LFS data. The LFS is therefore superior to the IS for data other than earnings information, such as the distribution of new immigrants across occupations, the characteristics of workers by occupation and skill group, etc. The 1989 LFS contains 92,469 observations, of which 13,529 are IS observations, and the 1994 LFS contains 102,688 observations, of which 15,399 are IS observations.

${ }^{19}$ The income data for the self-employed are not highly reliable.

20 The age difference between Russians and Israelis is 3.5 years if the sample is not restricted by age.
} 
Turning to labor market variables, Russians are more likely than Israelis to work fulltime. The average hourly wage of Israelis (calculated by dividing average monthly income from salaried work by weeks worked multiplied by average weekly hours) is 24.281994 NIS. $^{21}$ Russians earn about $45 \%$ less, with average hourly earnings of 13.461994 NIS. This large differential is consistent with other studies of new immigrants' labor market outcomes, relative to those of natives. The bottom panel of Table One shows the breakdown of Israelis and Russians by 1-digit occupation and industry. Russians are more likely than native Israelis to be in skilled or unskilled blue-collar jobs and in services. They are less likely to be managers or clerks. With respect to industry, Russians are overrepresented in manufacturing and underrepresented in the public sector, relative to Israelis.

\section{Results}

\section{A. Individual-Level Analysis}

\section{Ordinary Least Squares}

Table Two presents OLS estimates of the effect of immigration on the wages of native Israelis, as specified in equation (11). The unit of observation is the individual native worker, with the sample including employed natives between the ages of 25-65 who are not self-employed. The data are the pooled 1989 and 1994 Income Survey microdata.

The dependent variable in the regression is the log of hourly earnings. The explanatory variables include a piecewise linear function of years of schooling, a quartic in

\footnotetext{
21 The 1994 exchange rate was roughly 3 NIS (New Israeli Shekels) to the U.S. dollar.
} 
experience and dummy variables for sex, Arab ethnicity, Asian-African origin, immigrant status (and its interaction with years since migration), 1-digit industry, and 2-digit occupation. All of the control variables are also interacted with a year dummy (which also enters separately), except for the set of occupation dummies, which are time-invariant. The time-varying industry dummies capture changes in demand conditions, e.g., a positive shock to the construction industry during this period of high immigration.

The final independent variable in the equation, $r$, measures the presence of Russians in the individual's occupation. By definition, for observations in 1989, $r=0$. For observations in 1994, the value of $r$ is computed by 2-digit occupation using the 1994 Labor Force Survey, and equals the number of Russians employed in the occupation divided by the number of native Israelis employed in the occupation. The estimated coefficient on $r$ is .324 (s.e. of .103). This implies that a $10 \%$ increase in employment due to an influx of Russians is associated with a $3.8 \%$ fall in the hourly earnings of Israelis in that occupation. ${ }^{22}$ This estimated effect is stronger than most found in the literature. However, because OLS may yield biased results, we turn to IV estimation.

\section{Instrumental Variables}

Individual-level instrumental variables estimates of the impact of immigration on native wages are presented in Table Three. Each row of the table presents the results of a different regression. $\ln (w)$ denotes the log of individual hourly wages, $r$ measures the presence of immigrants currently working in the native's occupation, and $p$ measures the

\footnotetext{
22 This magnitude is quite close to the estimated coefficient of -.262 found in the equivalent specification by Altonji and Card (1991) in their cross-city study of immigration to the United States in the 1970 s [but $1 / 3$ of their IV coeff of -1.2 ]].
} 
presence of immigrants formerly working in the native's occupation. ${ }^{23}$

The first row of Table Three presents the first-stage equation for the two-stage least squares estimation, regressing $r$ on $p$ and the full set of control variables used in Table Two. Note that although $r$ and $p$ are occupation-level variables, this is an individual-level regression, since $X$ varies at the individual level. There is a significant positive relationship between $r$ and $p$. The coefficient on $p$ is .187 (s.e. .041) and the $R^{2}$ is .76 . Note that if there were no change in native employment by occupation over the five-year period, and if Russians did not change occupations following migration, this coefficient would equal one.

The second row of Table Three shows the reduced-form equation of log wages on $p$. Somewhat surprisingly, the point estimate of the coefficient is positive, but it is not statistically significant. ${ }^{24}$ Finally, row three shows the effect of $r$ on log wages, when $r$ is instrumented with $\mathrm{p}$, using 2SLS. The estimated coefficient, which had been significantly negative using OLS, is positive and insignificant in the instrumented estimation (coefficient of .718 , s.e. of .421$).^{25}$ While IV cannot reject the null hypothesis that $\gamma=0$, IV clearly rejects the OLS point-estimate of $\gamma$ (with $t=2.5$ ).

The contrast between the OLS and IV estimates at the individual-level indicate that the distribution of Russian immigrants across occupations in Israel was not independent of the unobserved determinants of wages in those occupations, and that as a result, OLS

\footnotetext{
${ }^{23}$ The variables referred to are defined above in section IV.B.3.

${ }^{24}$ A positive effect of immigration on native wages would be consistent with complementarity between immigrant and native workers within an occupation. In fact, there is substantial anecdotal evidence supporting such an effect, for example, in hi-tech firms and in medicine. Russian workers fill entry-level positions, pushing incumbent Israelis "up the ladder" into more senior supervisory roles.

${ }^{25}$ Variations in the sample-selection rules and in the particular set of control variables used sometimes yield t-statistics of over two, with similar point estimates.
} 
yields biased estimates of immigration's impact on native wages. The conclusion of the individual-level estimation is thus that the influx of Russians to a given occupation in Israel does not appear to have adversely affected the wage growth of natives working in that occupation.

\section{B. Occupation-Level Analysis of Wages}

As mentioned earlier, most of the literature studying immigration's impact on the receiving labor market has analyzed data at a level more aggregated than that of the individual. In order to compare individual- and group-level results, and because the source of variation in the instrument is at the occupation level, I now conduct a parallel analysis on occupation-level data.

There are two versions of this analysis, varying in their treatment of the control variables. The first version conducts the analysis on mean occupational wage and immigration variables, not conditioning on any covariates. The second version uses occupational differentials which are conditioned on the covariates used in the individual-level analysis.

\section{Unconditional Analysis}

Table Four assesses the impact of immigration on native wages using occupationlevel data which have not been corrected for any correlation with control variables such as education, experience, etc. Each column has a different dependent variable, and each row has a different independent variable, so that each number in the table is a coefficient from a different regression. 


\section{i. Levels}

The first column of Table Four shows the first-stage equation, in which $r$ is regressed on $\mathrm{p}$. This regression measures the strength of the relationship between the labor supply shock to an occupation that would be implied by the former occupational distribution of the immigrants and the actual ratio of Russians to native Israelis observed in the occupation expost. The estimated coefficient on $p$ is .204 (s.e. of .102), quite close to the estimate obtained in the individual-level data.

The relationship between $r$ and $p$ is shown graphically in Figure Six. The relatively flat line in the figure shows the predicted value of $r$ from an OLS regression of $r$ on $p$. The vertical distance of a given point from the 45-degree line shows the extent to which $r$ deviates from $\mathrm{p}$ for that occupation. Although the immigrant flow contained many engineers and doctors (relative to the size of those occupations in Israel), many of those people did not wind up working in those occupations in Israel. The occupations with the highest values of $r$ are unskilled workers.

The second column of Table Four evaluates the effect of immigrants on the level of $\log$ wages in 1994 . The uninstrumented weighted least-squares ${ }^{26}$ regression in the first row yields a coefficient of -1.49 (s.e. .343), indicating a very strong negative relationship between the presence of immigrants in an occupation and the wages of native Israelis in that occupation. The data and regression line are shown graphically in Figure Seven.

Because OLS may be biased, we again turn to IV. The reduced form equation in the

\footnotetext{
${ }^{26}$ The regressions are weighted by 1994 Israeli employment.
} 
second row of Table Four yields a significant positive relationship between log wages and $p$ (1.08, s.e. .256), which can be seen in Figure Eight. The weighted 2SLS estimate in the final row is not statistically significant (coefficient of 8.25 , s.e. 6.40 ), so that the bottom line of the occupation-level levels analysis is, again, that immigration does not appear to reduce wages. The difference between the OLS and IV results here indicates that the negative relationship between immigration and native wages in OLS is due not to an adverse impact of immigration on native wages, but rather to the fact that immigrants went disproportionately into low-paying occupations.

\section{ii. Changes}

For the reasons discussed in the section on empirical methodology above, an evaluation of the effect of changes in immigrant presence on changes in wages may be preferred to a levels analysis. The final column of Table Four shows the results of regressions in which the dependent variable is the change in the log occupational wage of native Israelis 1989-94.

Figure Nine shows the data and results of the uninstrumented regression of the change in log hourly earnings on $r$. The regression yields a strong negative coeffient of .578 (s.e. .190), indicating that a $10 \%$ increase in employment due to an influx of immigrants is associated with a $7.8 \%$ drop in native wages. This result is clearly not driven by outliers. It is somewhat stronger than the estimated effect of -.324 found in the individual-level analysis. It is noteworthy that the coefficient in the changes equation is weaker than the coefficient in the levels equation. This provides further evidence that the negative cross-sectional correlation between immigration and native wages reflects the fact 
that Russians went into low-paying occupations, rather than any adverse impact of immigration on native wages.

This is confirmed in IV estimation. The reduced form equation of the change in the log wage on $\mathrm{p}$ yields an insignificant positive coefficient (seen in Figure Ten). The weighted2SLS coefficient in the final row, showing the effect of $r$ on the change in the log wage, when $r$ is instrumented with $p$, is also positive but not statistically significant. IV cannot reject the null hypothesis of $\gamma=0$, but IV does reject the OLS point-estimate (with $t=3.1$ ). The conclusion of the occupation-level analysis, when the variables are not conditioned on any controls, is that we cannot reject the hypothesis that immigration had no effect on native wages or wage growth. These findings are qualitatively the same as those of the individual-level estimation.

\section{Conditional Analysis}

The analysis of the previous section can be repeated using variables which have been purged of correlation with the vector of control variables, $\mathrm{X}$. The conditional variables are calculated by regressing the variable of interest on the full vector of control variables, $X$, in the individual-level data, and using the coefficients on the occupation dummies as the variables in the occupation-level analysis. Table Five shows this analysis. The results are

not qualitatively different from the unconditional analysis. Both the level and growth of wages are found to be lower in occupations with a high ratio of Russian workers. In terms of size, the negative effect of $r$ on wages and wage growth becomes stronger, but this effect is again insignificant in the instrumented estimation. 


\section{Discussion}

There is a negative cross-sectional relationship between native wages and the presence of Russian immigrants in an occupation. This is consistent with immigrants having had an adverse impact on native pay. However, if immigrants' entry into occupations was not independent of wages, OLS is biased. One approach to obtaining unbiased estimates is first-differencing. The relationship between native wage growth over the period when the immigrants arrived and immigrant entry into an occupation shows a weaker negative relationship between immigration and wages than exists in the cross-section. This implies that some of the cross-sectional relationship is due to the fact that immigrants entered low wage occupations, rather than being fully attributable to a depressing effect of immigration on wages. However, because the changes relationship could also be tainted by endogeneity, instrumental variables is used, with the result that the OLS point estimate is rejected. Immigration is found to have an insignificant positive correlation with native wages. This implies that the negative relationships found by OLS were due entirely to immigrants entering low wage ${ }^{27}$ low wage-growth occupations and not to any adverse impact of the immigration on native wages.

\section{Occupation-Level Analysis of Employment}

Having found that immigration did not lower the wages of natives, it is interesting to investigate whether there was an impact in the employment dimension. Evidence of native displacement would provide support for the argument that the lack of a wage effect was

\footnotetext{
${ }^{27}$ This is confirmed in regressions of 1994 immigrant employment on 1989 native wages, which yield statistically significant negative coefficients.
} 
due to offsetting movements of native workers out of those occupations into which the immigrants flowed.

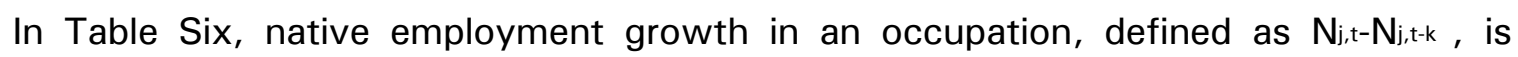

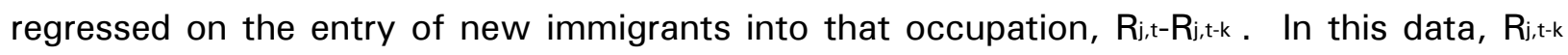
equals zero, so the change in the number of natives employed in an occupation from 1989 to 1994 is simply regressed on the number of Russians employed in the occupation in 1994.

Each number in Table Six is a coefficient from a different regression. The top row of the table shows unweighted and weighted least-squares regression coefficients. Both are negative, but small and statistically insignificant. The point estimates imply that, at most, for every six new Russian workers, one native worker left the occupation. The relationship between $\Delta N$ and $R$ is shown graphically in Figure Eleven. The line through the data shows the predicted valued of $\Delta \mathrm{N}$ from the unweighted OLS regression.

Just as in the wage analysis, however, OLS may be biased. R may be positively correlated with the error term because both native and immigrant workers are drawn to occupations with good characteristics. This would lead to upward bias in the OLS coefficient and an underestimate of immigration's adverse employment impact. Alternatively, R may be negatively correlated with the error term, if Russians can only get work in occupations with undesirable characteristics. To get around this bias, we again use 2SLS estimation, instrumenting for $\mathrm{R}$ with $\mathrm{P}$.

The first column of Table Six shows the first-stage equation, regressing $R$ on $P$, i.e., the number of Russians employed in each occupation in Israel on the number who were employed in each occupation in Russia. The estimated coefficient on P is .283 (s.e. .075). As previously shown in Figure Four, the correlation between the two variables is quite 
strong, with a correlation coefficient of .37 (i.e., $R^{2}$ of .14).

Figure Twelve plots the change in native employment, $\Delta \mathrm{N}$, on the number of Russians in the occupation abroad, P. The OLS reduced-form regression line has a statistically insignificant positive slope (shown in the second row of Table Six). The 2SLS estimates in the bottom row of Table Six are positive and statistically insignificant. Although all estimates are insignificant, the 2SLS point estimates have reversed the sign of OLS.

The conclusions of the employment analysis are therefore similar in spirit to those of the wage analysis. OLS shows a negative (if insignificant) relation between native employment growth and immigrant entry. Because of the potential endogeneity of immigrant entry into an occupation, it is unclear whether we can conclude that natives were displaced by immigrants. Instrumenting for the native inflow with the immigrants' occupational distribution abroad shows that the negative OLS relationship is not in fact due to displacement of natives by immigrants, but rather to the fact that immigrants went into contracting occupations. This is consistent with the evidence given above that immigrants went into low wage, low wage-growth occupations. The entry of immigrants into "bad" jobs may be attributed to their inferior Hebrew-language skills and the imperfect transferability of their human capital only five years following immigration. It is also consistent with ranking or discrimination in the labor market.

These results indicate that it was not native outflows which prevented wages from falling in occupations with heavy immigrant inflows. An alternative explanation-- such as highly elastic labor demand, an inflexible labor market, or a change in the composition of native employment-- will have to be found. Note that demand expansion is not a 
satisfactory explanation of these results, since it is unlikely that demand expanded in proportion with labor supply across occupations. 


\section{Conclusion}

The recent mass migration to Israel from the former Soviet Union provides a natural experiment for the study of immigration's impact on the labor market outcomes of natives. An analysis of microdata on the earnings of native Israelis before and after the migration, using OLS estimation, indicates that natives in occupations which received more immigrants experienced lower earnings growth over the period 1989-94. A $10 \%$ increase in occupational employment due to immigration is associated with a $3.8 \%$ decrease in the real hourly earnings of natives in that occupation. An analysis of occupation-level wage data yields even stronger effects of between $7 \%$ and $10 \%$. There is, at most, weak evidence of a negative impact on native employment levels.

Because the distribution of immigrants across occupations may not have been independent of relative labor market conditions across occupations, an instrumental variables approach is used to reestimate the relationship between immigration and native wages and employment. There is a significant positive correlation between the occupations which the Russian immigrants held abroad and the occupations they hold in Israel. The occupational distribution of the Russians in Russia was exogenous to wage and employment growth in Israel following their migration. The former occupational distribution of the immigrants can therefore be used as a source of exogenous variation in their occupational distribution in Israel. When previous occupations are used to instrument for current occupations, two-stage least squares yields estimates which reject the OLS point-estimates for wage growth and are not significantly different from zero for employment. We cannot reject the hypothesis that the mass migration of Russians to Israel did not affect the earnings or employment of native Israelis, and the point estimates are inconsistent with a negative 
impact. These findings imply that the negative relationships found using OLS are due entirely to immigrants entering occupations with low wages, low wage growth, and contracting employment, rather than to any adverse impact of the immigrants on native labor market outcomes. 


\section{References}

Altonji, Joseph and David Card. "The Effects of Immigration on the Labor Market Outcomes of Less-skilled Natives". In J. Abowd and R. Freeman eds. Immigration, Trade and the Labor Market. Chicago: University of Chicago Press, 1991, pp.201-34.

Angrist, Joshua. "Short-Run Demand for Palestinian Labor," Journal of Labor Economics, vol.14, no.3, July 1996, pp.425-53.

Beenstock, Michael, and Yitzhak Ben Menahem, "The Labour Market Absorption of CIS Immigrants to Israel: 1989-1994," Falk Institute Discussion Paper 95.05, Dec. 1995.

Beenstock, Michael and Jeffrey Fisher "The Macroeconomic Effects of Immigration: Israel in the 1990s," unpublished manuscript, Aug. 1996.

Borjas, George. "Immigrants, Minorities, and Labor Market Competition," Industrial and Labor Relations Review, vol. 40, no. 3, April 1987, pp.382-92.

Borjas, George, Richard Freeman and Lawrence Katz. "On the Labor Market Effects of Immigration and Trade." In G. Borjas and R. Freeman eds. Immigration and the Work Force: Economic Consequences for the United States and Source Areas. Chicago: University of Chicago Press, 1992, pp.213-44.

Borjas, George, Richard Freeman and Lawrence Katz. "Searching for the Effect of Immigration on the Labor Market". American Economic Review, May 1996.

Borjas, George, Richard Freeman and Lawrence Katz. "How Much Do Immigration and Trade Affect Labor Market Outcomes?" Brookings Papers on Economic Activity, 1:1997.

Borjas, George, and Valerie Ramey. "Foreign Competition, Market Power and Wage Inequality: Theory and Evidence." Quarterly Journal of Economics, vol.110, no.4, November 1995, pp.1075-1110.

Brezis, Elise, and Paul Krugman, "Immigration, Investment, and Real Wages," Journal of Population Economics, vol. 9, no. 1, Feb. 1996, pp.83-93.

Butcher, Kristin and David Card, "Immigration and Wages: Evidence from the 1980s," American Economic Review, 1991, vol.81, pp.292-6.

Card, David, "Immigrant Inflows, Native Outflows, and the Local Labor Market Effects of Higher Immigration," NBER Working Paper 5927, 1997.

Card, David. "The Impact of the Mariel Boatlift on the Miami Labor Market." Industrial and Labor Relations Review, January 1990, vol.43, no.2, pp.245-57. 
Carrington, William and Pedro deLima, "Large-Scale Immigration and Labor Markets: An Analysis of the Retornados and Their Impact on Portugal," Industrial and Labor Relations Review, January 1996, pp.330-47.

Eckstein, Zvi and Ron Shachar, "On the Transition to Work of New Immigrants 1990-92," Falk Institute Discussion Paper 95.04, Aug. 1995.

Flug, Karnit and Nitsa (Kaliner) Kasir, "The Absorption in the Labor Market of Immigrants from the CIS-- the Short Run," Bank of Israel Discussion Paper 93.09, Oct. 1993.

Flug, Karnit, Nitsa (Kaliner) Kasir, and Gur Ofer, "The Absorption of Soviet Immigrants into the Labor Market from 1990 Onwards: Aspects of Occupational Substitution and Retention," Bank of Israel Discussion Paper 92.13, Nov. 1992.

Flug, Karnit, Zvi Hercowitz, and Anat Levi, "A Small- Open- Economy Analysis of Migration," Foerder Institute Working Paper 13-94, June 1994.

Friedberg, Rachel and Jennifer Hunt, "The Impact of Immigrants on Host Country Wages, Employment and Growth," Journal of Economic Perspectives, vol.9, no.2, Spring 1995, pp. 23-44.

Goldin, Claudia. "The Political Economy of Immigration Restriction in the United States, 1890-1921." In C. Goldin and G. Libecap eds. The Regulated Economy: a Historical Approach to Political Economy. Chicago: The University of Chicago Press, 1994.

Hercowitz, Zvi and Leora Rubin Meridor, "Macroeconomic Implications of Mass Immigration to Israel," Foerder Institute Working Paper 29-91, 1991.

Hercowitz, Zvi and Leora Rubin Meridor, "Macroeconomic Ramifications of the Mass Immigration Into Israel: An Update and Reexamination," The Economic Quarterly, Anno 40 no.3, 377-390, Oct. 1993.

Hercowitz, Zvi, Nirit Kantor, and Leora Rubin Meridor, "Immigration and Growth Under Imperfect Capital Mobility: The Case of Israel," Sackler Institute Working Paper 12-93, June 1993.

Hunt, Jennifer. "The Impact of the 1962 Repatriates from Algeria on the French Labor Market." Industrial and Labor Relations Review, April 1992, vol.45, no.3, pp.556-72.

Jaeger, David. "Skill Differences and the Effect of Immigrants on the Wages of Natives." U.S. Bureau of Labor Statistics manuscript, 1996.

LaLonde, Robert and Robert Topel. "Labor Market Adjustments to Increased Immigration." In J. Abowd and R. Freeman ed. Immigration, Trade and the Labor Market. Chicago: University of Chicago Press, 1991, pp.167-99. 
Moulton, Brent. "Random Group Effects and the Precision of Regression Estimates," Journal of Econometrics, vol.32, 1986, pp.385-397.

Pischke, Jörn-Steffen and Johannes Velling. "Wage and Employment Effects of Immigration to Germany: An Analysis Based on Local Labor Markets." MIT Working Paper 94-8, January 1994.

Pope, David and Glenn Withers. "Do Migrants Rob Jobs? Lessons of Australian History, 1861-1991." Journal of Economic History, December 1993, vol.53, no.4, pp.719-742.

Schoeni, Robert F. "The Effect of Immigrants on the Employment and Wages of Native Workers: Evidence from the 1970s and 1980s," unpublished manuscript, Rand Corporation, 1996.

Weiss, Yoram and Menachem Gotlibovski, "Immigration, Search and Loss of Skill," Foerder Institute Working Paper 34-95, Nov. 1995.

Weiss, Yoram and Nissim Ben David, "The Effect of Business Cycles and Immigration on Labour Market Flows in Israel," Golda Meir Institute Working Paper 75, Oct. 1994. 


\section{APPENDIX: \\ 2-Digit Occupation Codes}

00 professionals in life sciences

01 academic professionals in natural sciences

02 engineers and architects

03 physicians and dentists

04 pharmacists and veterinarians

05 jurists

06 social sciences workers

07 workers in humanities

08 higher education teachers

09 teachers in second. and post-second. education

$0+$ academic professionals ns

10 teachers in intermed. and prim. schools, kinderg.

11 accountants and cost accountants

12 workers in religion

13 authors, artists, composers, journalists

14 social workers and probation officers

15 nurses and other para-medical professions

16 natural sciences technicians

17 engineering technicians

18 system analysts, programmers

19 technicians and other free professionals nec

$1+$ technicians ns

20 legislative and executive authorities

21 managers in public services

22 managers of units for natural sciences

23 managers of units for humanities, social sciences

24 other managers

$25 * * * * * * * * * *$

$26 * * * * * * * * * *$

27

28

$29 * *$

$2+$ managers ns

30 supervisors

31 accounts clerks

32 secretaries, typists, etc.

33 warehouse and filing clerks

34 teleph., telegraph, radio operators

35 transport supervisors

36 postmen, inspectors, conductors

37 clerks (general)

38 clerks nec 
$39 * * * * * * * * *$

$3+$ clerks ns

40 wholesalers (proprietors)

41 retailers (proprietors)

42 agents, commercial travellers

43 insurance, estate agents and appraisers

44 salesmen

45 peddlers etc.

$46 * * * * * * * * * *$

$47 * * * * * * * * * *$

$48 * * * * * * * * *$

$49 * * * * * * * * *$

$4+$ merchants and agents ns

50 proprietors in lodging and catering services

51 cooks

52 waiters, barmen

53 housekeepers and room cleaners

54 housemaids

55 launderers

56 hairdressers, beauticians

57 policemen, firemen, etc.

58 guides, stewards, dental assistants

59 other service workers nec

$5+$ service workers ns

60 famers (proprietors)

61 farm supervisors

62 skilled farm workers

63 fishermen

64 farm machinery operators

65 packing and sorting workers

66 unskilled ag. workers

$67 * * * * * * * *$

$68 * * * * * * * *$

$69 * * * * * * * *$

$6+$ agricultural workers ns

70 metal processors

71 locksmiths, welders, tinsmiths

72 machinery assemblers and repairers

73 pipe fitters and plumbers

74 electricians (incl. electronic products)

75 precision instr., watchmakers, goldsmiths

76 diamond workers

77 skilled workers-- food, beverages, tobacco 78 wood workers, carpenters, etc. 
79 spinning, weaving workers

$7+$ industrial foremen ns

80 tailors, dressmakers, etc.

81 shoe repairs and other leather products workers

82 printing workers

83 other industrial craftsmen

84 miners, quarrymen

85 builders

86 construction machine operators

87 ships' and railway workers

88 drivers

89 painters

$8+$ skilled workers ns

90 dockers, porters

91 unskilled workers in chemicals and minerals

92 unskilled workers in rubber and plastic $\mathrm{mfg}$

93 unskilled workers in food, beverage, and tobacco

94 engine and pump operators

95 packers

96 workers in non-metallic minerals

97 workers in industry nec

98 construction workers nec

99 unskilled workers ns

$9+$ unskilled workers ns 
Table One: Summary Statistics

\begin{tabular}{|c|c|c|}
\hline & Israelis & Russians \\
\hline Age & $\begin{array}{c}40.5 \\
(10.2)\end{array}$ & $\begin{array}{c}41.5 \\
(9.9)\end{array}$ \\
\hline Years of Schooling & $\begin{array}{c}13.0 \\
(13.3)\end{array}$ & $\begin{array}{l}14.0 \\
(2.7)\end{array}$ \\
\hline Female (\%) & 45.3 & 45.6 \\
\hline Arab (\%) & 4.4 & 0.0 \\
\hline Asia-Africa Origin (\%) & 47.3 & 0.0 \\
\hline Immigrant (\%) & 39.2 & 100.0 \\
\hline Years Since Migration & $\begin{array}{c}31.5 \\
(12.3)\end{array}$ & $\begin{array}{c}3.1 \\
(1.1)\end{array}$ \\
\hline Full-Time (\%) & 63.6 & 72.6 \\
\hline $\begin{array}{l}\text { Hourly Wage } \\
\text { (1994 NIS*) }\end{array}$ & $\begin{array}{c}24.28 \\
(19.67)\end{array}$ & $\begin{array}{c}13.46 \\
(10.59)\end{array}$ \\
\hline \multicolumn{3}{|l|}{ Occupational Composition of Employment: } \\
\hline O Scientific and Academic Professionals & 11.0 & 11.5 \\
\hline 1 Other Free Professionals, Technicians, etc. & 18.7 & 11.4 \\
\hline 2 Managers & 7.0 & .4 \\
\hline 3 Clerks & 19.3 & 5.8 \\
\hline 4 Sales Workers, Agents, etc. & 7.5 & 4.3 \\
\hline 5 Service Workers & 12.5 & 21.5 \\
\hline 6 Farm Workers & 1.3 & 2.0 \\
\hline 7 Skilled Workers in Ind., Transp., Const. I & 11.1 & 23.1 \\
\hline 8 Skilled Workers in Ind., Transp., Const. II & 9.7 & 11.0 \\
\hline 9 Unskilled Workers in Ind., Transp., Const. & 2.1 & 9.0 \\
\hline \multicolumn{3}{|l|}{ Industrial Composition of Employment: } \\
\hline O Agriculture & 1.0 & 1.7 \\
\hline 1 Industry I (Mining, Manufacturing) & 8.7 & 18.0 \\
\hline 2 Industry II (Mining, Manufacturing) & 12.9 & 19.8 \\
\hline 3 Electricity and Water & 1.4 & 1.2 \\
\hline 4 Construction & 4.7 & 6.9 \\
\hline 5 Commerce, Restaurants, Hotels & 12.5 & 11.7 \\
\hline 6 Transport, Storage and Communication & 6.6 & 3.0 \\
\hline 7 Financing and Business Services & 12.2 & 8.6 \\
\hline 8 Public and Community Services & 34.7 & 19.5 \\
\hline 9 Personal and Other Services & 5.3 & 9.7 \\
\hline
\end{tabular}


Data Source: 1994 Israel Income Survey and Labor Force Survey. Sample is non-self-employed employed people aged 25-65. "The 1994 exchange rate was roughly 3 NIS to the U.S. dollar. 
The Impact of Immigration on Native Israeli Wages Individual-Level Analysis: OLS

\begin{tabular}{|c|c|c|c|c|}
\hline & Control Va & ables & $\begin{array}{r}\text { Interactior } \\
\text { Variables } \mathrm{W}\end{array}$ & $\begin{array}{l}\text { mintrol } \\
\text { mmy for }\end{array}$ \\
\hline & Coefficient & S.E. & Coefficient & S.E \\
\hline Constant & 1.36 & (.16) & .299 & $(.180)$ \\
\hline Years of Educ 1-8 & .0333 & $(.0127)$ & -.00774 & $(.02060)$ \\
\hline Years of Educ 9-11 & .0419 & $(.0114)$ & .00360 & $(.0172)$ \\
\hline Years of Educ 12 & .0264 & $(.0261)$ & .0550 & $(.0377)$ \\
\hline Years of Educ 13-14 & .0765 & $(.0122)$ & .0101 & $(.0161)$ \\
\hline Years of Educ $15+$ & .0406 & $(.0062)$ & -.0114 & $(.0079)$ \\
\hline Experience & .0343 & $(.0116)$ & .0420 & $(.0159)$ \\
\hline $\operatorname{Exp}^{2} / 100$ & -.0914 & (.0927) & -.260 & $(.129)$ \\
\hline $\operatorname{Exp}^{3} / 1000$ & .0092 & $(.0283)$ & .0617 & $(.0402)$ \\
\hline $\operatorname{Exp}^{4} / 10000$ & -.0003 & $(.0029)$ & -.00487 & $(.00418)$ \\
\hline Female & -.212 & $(.018)$ & .0216 & $(.0234)$ \\
\hline Arab & -.0705 & $(.0392)$ & .0339 & $(.0551)$ \\
\hline Asia-Africa & -.0802 & $(.0165)$ & .0476 & $(.0233)$ \\
\hline Immigrant & -.178 & $(.030)$ & -.0187 & $(.0463)$ \\
\hline Years Since Migration & .00513 & $(.00096)$ & .000997 & $(.00143)$ \\
\hline Agriculture & .119 & $(.096)$ & -.019 & $(.117)$ \\
\hline Mining and Mfg.I & -.0134 & $(.0462)$ & .0674 & $(.0582)$ \\
\hline Mining and Mfg.II & .116 & $(.043)$ & .0707 & $(.0544)$ \\
\hline Elec. and Water & .408 & $(.074)$ & .0458 & $(.0993)$ \\
\hline Construction & .0446 & $(.0614)$ & .0868 & $(.0733)$ \\
\hline Commerce & -.0145 & $(.0445)$ & .0587 & $(.0557)$ \\
\hline Transp. and Comm. & .156 & $(.048)$ & .102 & $(.0623)$ \\
\hline Financial and Bus. & .113 & $(.044)$ & .0612 & $(.0566)$ \\
\hline Public Services & .0138 & (.0395) & .123 & $(.050)$ \\
\hline $\begin{array}{l}\text { Presence of } \\
\text { the Individu }\end{array}$ & $\begin{array}{l}\text { ussians in } \\
\text { s Occupation }\end{array}$ & & $\begin{array}{l}-.324 \\
(.103)\end{array}$ & \\
\hline$R^{2}$ & & & 0.534 & \\
\hline Number of & servations & & 8,353 & \\
\hline
\end{tabular}

Note: Standard errors in parentheses. Individual-level data are from pooled IS 1989 and 1994. Occupation-level data are from LFS 1994. Dependent variable is log hourly wage of native Israelis. Sample excludes new immigrants, the self-employed, and those below age 25 or above age 65 . 
Regression also includes a set of 2-digit occupation dummies. " $r$ " is the number of Russians in the individual's occupation divided by the number of native Israelis in that occupation. 


\section{Table Three}

The Impact of Immigration on Native Israeli Wages Individual Level Analysis: 2SLS

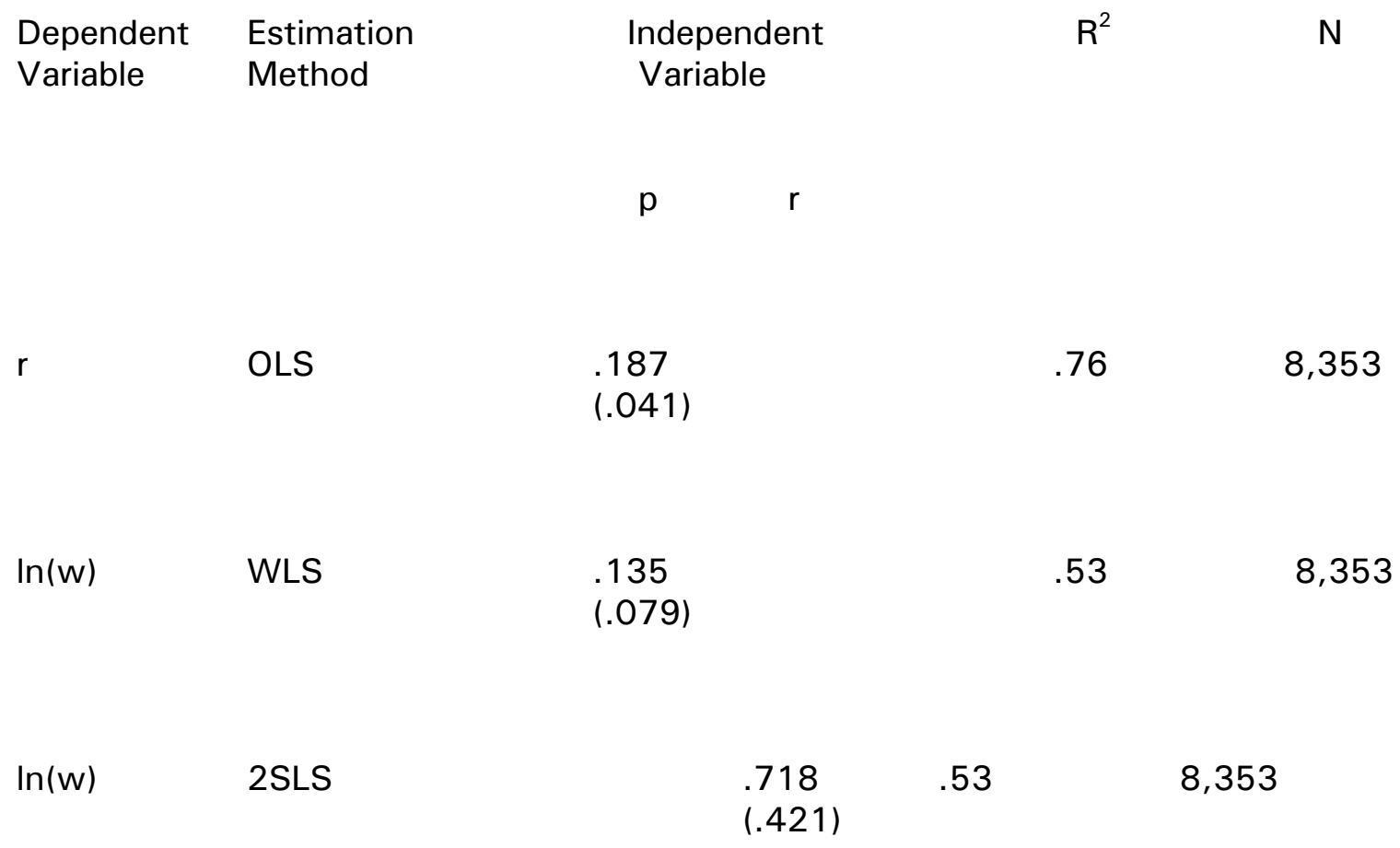

Note: Standard errors are in parentheses. Robust standard errors, which correct for clustering by occupation, are reported for the first regression. Individual-level data are from 
pooled IS 1989 and 1994. Occupation level data are from LFS 1994. "In(w)" is the log hourly wage of native Israelis. Sample excludes new immigrants, the self-employed, and those below age 25 or above age 65. Regressions also include all of the control variables used in Table Two. 


\section{Table Four}

\section{Occupation-Level Wage Analysis}

Unconditional Mean Wages on Unconditional Mean Immigrant Presence

Dependent Variable:

$\begin{array}{ccc}\text { Unconditional Log Wage } & \text { Change in Log Wage } \\ r & \text { of Israelis } & \text { of Israelis } \\ 1994 & 1989-94\end{array}$

OLS/WLS Independent Variable:

Unconditional $r$

Unconditional $\mathrm{p}$

.204

(.102)

1.08

(.256)

.050

(.149)

W2SLS Independent Variable:

Unconditional $r$

Instrumented with

Unconditional $p$
8.25

(6.40)
.383

(.308)

Note: Each coefficient comes from a separate regression. Variables are unconditional means by 2-digit occupation. Wage measure is the log of average hourly earnings. " $r$ " is $R / N_{1}$, where $R$ is the number of Russians employed in the occupation in 1994, and $N 1$ is the number of native Israelis employed in the occupation in 1994. "p" is P/No, where $P$ is the number of Russians employed in the occupation in Russia, and No is the number of native 
Israelis employed in the occupation in 1989. The data source for the wage variables is the 1989 and 1994 IS and for the immigrant presence variables is the 1994 LFS and 1990 IES. The regressions in the second and third columns are weighted by 1994 Israeli employment. 


\section{Table Five \\ Occupation-Level Wage Analysis \\ Conditional Mean Wages on Conditional Mean Immigrant Presence}

Dependent Variable:

$\begin{array}{ccc}\begin{array}{c}\text { Conditional } \\ r\end{array} & \begin{array}{c}\text { Residual } \\ \text { Log Wage } \\ \text { of Israelis }\end{array} & \begin{array}{c}\text { Change in Residual } \\ \text { Log Wage } \\ \text { of Israelis } \\ 1994\end{array} \\ & 1989-94\end{array}$

OLS/WLS Independent Variable:

Conditional $r$

$-1.04$

Conditional $\mathrm{p}$

.212

1.10

.230

(.098)

$(.362)$

$(.241)$

W2SLS Independent Variable:

Conditional $r$

Instrumented

7.64

(5.88)

(2.15)

with Conditional $\mathrm{p}$

Note: Each coefficient comes from a separate regression. Variables are conditional means by 2-digit occupation. Conditional $r$ and $p$ are the coefficients on the set of 2-digit occupation dummy variables in a regression of unconditional $r$ or $p$ on the full vector of 
covariates shown in Table Two. The data source for the log hourly wage variable is the 1989 and 1994 IS. The data source for the immigrant presence variables is the 1994 LFS and 1990 IES. The regressions in the second and third columns are weighted by 1994 Israeli employment. 


\section{Table Six}

Occupation-Level Employment Analysis Unconditional Change in Native Employment on Unconditional Immigrant Employment

Dependent Variable:

\begin{tabular}{cll} 
Unconditional Change in & \multicolumn{2}{c}{ Change in } \\
$\mathrm{R}$ & Employment & Employment \\
of Israelis & of Israelis \\
$1989-94$ & $1989-94$ \\
& (unweighted) & (weighted)
\end{tabular}

OLS/WLS Independent Variable:

Unconditional R

$-.0394$

$-.165$

$(.125)$

$(.120)$

Unconditional P

.283

.161

(.099)

.169

(.075)

(.098)

2SLS/W2SLS Independent Variable:

Unconditional $\mathrm{R}$

.537

1.86

Instrumented with

(.370)

(2.20)

Unconditional $P$

Note: Each coefficient comes from a separate regression. Standard errors are in parentheses. The dependent variable in columns two and three is the change in the number of natives employed in 2-digit occupation between 1989 and 1994. "R" is the number of Russians 
employed in the occupation in 1994. "P" is the number of Russians employed in the occupation in Russia. The data sources are the 1989 and 1994 LFS and the 1990 IES. The regressions in the third column are weighted by 1989 Israeli employment. 